\title{
Association between Migraine and Asthma in School Age Children
}

\author{
Serkan Kirik $^{1 \star}$, Mehmet Yasar Ozkars ${ }^{2}$
}

${ }^{1}$ Kahramanmaras Sutcu Imam University Department of Pediatric Neurology, TURKEY

${ }^{2}$ Kahramanmaras Sutcu Imam University Department of Pediatrics, TURKEY

*Corresponding Author: srknkrk@hotmail.com

Citation: Kirik S, Ozkars MY. Association between Migraine and Asthma in School Age Children. Electron J Gen Med. $2021 ; 18(5): e m 312$. https://doi.org/10.29333/ejgm/11100

\section{ARTICLE INFO}

Received: 10 Feb. 2021

Accepted: 1 Jul. 2021

\begin{abstract}
Background: Asthma and migraine are the most common chronic conditions. Few studies have concurrently evaluated the bidirectional association between asthma and migraine in pedaitric patients.

Objective: We aimed to identify the relationship between these conditions.

Methods: This retrospective study was carried out in a tertiary center. School-age patients diagnosed with migraine were included in the study by evaluating electronic patient files who complain with headache. These patients were diagnosed with asthma by a pediatric allergist.

Results: Of 5242 patients whose medical records were accessed. The number of patients with asthma who were referred to the pediatric neurology department for headache during the study period was 1427 (913 girls/514 boys). Two hundred and thirty-six (15.5\%) patients were diagnosed with migraine. At the same period, 3815 (2193 girls/1622 boys) patients without asthma presented to the pediatric neurology department for the evaluation of headache. Of those, $207(5.4 \%)$ patients were diagnosed with migraine. The frequency of migraine was significantly higher in patients with asthma than those without asthma $(\mathrm{OR}=1.84(95 \% \mathrm{Cl} 1.62-2.05), \mathrm{P}<0.001)$.

Conclusion: The risk of migraine is significantly increased in school age children with asthma. This study is very important in that it is one of the largest pediatric studies performed so far in our country.
\end{abstract}

Keywords: asthma, migraine, childhood

\section{INTRODUCTION}

Asthma and migraine are the most common chronic conditions [1]. The prevalence of asthma and similar allergic conditions has significantly increased in recent years, and in current studies it has been reported to be around $8 \%$ to $10 \%$ in childhood $[2,3]$. Migraine has a reported prevalence of around $11 \%$ in the adult population worldwide [4]. In childhood it is seen with a prevalence of $3.3 \%$ to $21.4 \%$, and is more common in older children and girls [5]. Although asthma is a respiratory disease and migraine is a neurological one, the relationship between the two diseases is striking, and childhood studies on this subject have recently gained pace [6]. Indeed, asthma has been formerly designated as "acephalic migraine" or "pulmonary migraine" [7]. In addition, it has been reported that the risk of migraine was greater in adults with asthma than those without. Furthermore, the prevalence of migraine has been reported to be greater in women than men $[8,9]$.

Asthma in adolescents is mostly allergic in nature, and allergic asthma accompanying migraine has been linked to inflammatory mediators, such as histamine and prostaglandins, which are produced by mast cells. Mast cell degranulation activates the pain pathway underlying migraine headache. Some studies have shown that asthma diagnosis predates the onset of chronic migraine $[9,10]$. A large-scale US study showed that asthma was associated with an increased risk of new-onset chronic migraine among individuals with episodic migraine [11]. The aim of this study was to determine the migraine frequency and the relevant clinical characteristics in pediatric patients presenting to two different clinics with asthma during a period of 3 years.

\section{MATERIALS AND METHODS}

This study included patients followed with asthma in Kahramanmaraş Sütçü İmam University Faculty of Medicine Hospital and Aydın Maternity and Children's Hospital, who were referred to the pediatric neurology outpatient clinic with headache between June 2017 and May 2020. The age range of the patients was 7 to 18 years. The number of patients who presented with headache during that period was 5242. Among those patients, the number of patients who were under followup for asthma was 1427. Sixteen patients whose medical records could not be accessed or who were found to have a secondary cause of headache [idiopathic intracranial hypertension, intracranial mass-occupying lesion etc.] were excluded.

a. Diagnosis of asthma: The patients' medical records and medical investigations were reviewed in detail. Among patients who were diagnosed with asthma according to the American Thoracic Society Guideline [12] and the current GINA guideline [13] based on the results of medical investigations including 
Table 1. Distribution of patients with age groups according to the gender, age and diagnosed with-without asthma

\begin{tabular}{|c|c|c|c|}
\hline & $\mathbf{n}$ & Male & Female \\
\hline Gender & 5242 & 2136 & 3106 \\
\hline Age & $14.81 \pm 2.36$ & $14.47 \pm 3.12$ & $14.92 \pm 2.98$ \\
\hline Asthma & 1427 & 514 & 913 \\
\hline$<12$ age & 503 & 169 & 334 \\
\hline$>12$ age & 924 & 345 & 579 \\
\hline Asthma + migraine & 236 & 72 & 164 \\
\hline$<12$ age & 74 & 23 & 51 \\
\hline$>12$ age & 172 & 49 & 113 \\
\hline Headache WoA & 3815 & 1622 & 2193 \\
\hline$<12$ age & 1256 & 587 & 669 \\
\hline$>12$ age & 2559 & 1035 & 1524 \\
\hline Migraine + WoA & 207 & 63 & 144 \\
\hline$<12$ age & 68 & 25 & 43 \\
\hline$>12$ age & 139 & 38 & 101 \\
\hline
\end{tabular}

Abb.: n: number; WoA: without asthma

spirometry recordings and methacholine test, those whose medical records were accessed were considered positive for the asthma diagnosis and included in the study.

b. Migraine headache: The medical records of patients who presented with headache were reviewed. Patients who met the diagnostic criteria of migraine according to the ICHD-3 Beta diagnostic criteria [14] and its pediatric revision [15] were included in the study. Patients who lacked medical tests such as neuroimaging and ophthalmological examination for conditions that potentially cause secondary headache were excluded from the study.

\section{Statistical Analysis}

Patient characteristics and their rates were defined. Chisquare test was used to compare categoric variables between the study groups. Odds ratios [OR] and 95\% confidence intervals $[95 \% \mathrm{Cl}]$ were calculated. A p value of less than 0.05 was considered statistically significant for all statistical analyses. All study data were generated using the SPSS statistics software package, version 22.0 (IBM Corp., Armonk, New York).

\section{RESULTS}

Of 5242 patients whose medical records were accessed, 2136 were male and 3106 were female. The mean age of the patients was $14.81 \pm 2.36$ (7-18) years. The patients with asthma had a mean age $14.72 \pm 2.43$ years; the patients with headache but without asthma had a mean age of $14.12 \pm 3.07$ years. The number of patients with asthma who were referred to the pediatric neurology department for headache during the study period was 1427 (913 girls/514 boys). Two hundred and thirtysix (15.5\%) patients were diagnosed with migraine. At the same period, 3815 (2193 girls/1622 boys) patients without asthma presented to the pediatric neurology department for the evaluation of headache. Of those, 207 (5.4\%) patients were diagnosed with migraine. Two hundred and thirty-six patients were included in the study, and the data of 72 boys and 164 girls were analyzed. Detailed information about the study participants is presented on Table 1. The frequency of migraine was significantly higher in patients with asthma than those without $[\mathrm{OR}=1.84(95 \% \mathrm{Cl}(1.62-2.05), \mathrm{P}<0.001)$. An analysis of the sex-based distribution of migraine frequency revealed that migraine was more frequent in girls than boys in both patient groups with $(\mathrm{OR}=1.62(1.49-1.76) \mathrm{P}<0.0001)$ and without
(OR=1.74 (1.48-1.92) $\mathrm{P}<0.0001)$ asthma. It was found that the frequency of asthma showed a significant rise after the age of 12 years in both sexes in both patient groups with and without asthma $(P<0.0001)$.

\section{DISCUSSION}

Migraine and asthma are widespread chronic medical disorders with episodic exacerbations as a prominent feature, which can be associated with many important disorders. While they are more common in young adults, they are more common in women than men $[8,11,16]$. Our study demonstrated that the relative risk of migraine as a comorbidity increased 1.84 times in individuals with asthma. Similarly, in a questionnaire-based study, Aamodt et al. reported that the likelihood of both migraine and non-migraine headache was approximately 1.5 times greater among individuals with asthma than those without [17]. In a large matched case-control study on migraine based on the opposite hypothesis, which included individuals born in the United Kingdom between 1891 and 2000, the risk of asthma was found to be 1.59 times greater in patients with migraine compared to individuals who had no migraine [18].

In a study by Lateef et al., it was shown that adolescents with migraine showed more frequent symptoms of asthma and allergic rhinitis than those without migraine [20]. Peng et al. found that migraine was 1.45 times more prevalent in patients with asthma than those without [20]. A domestic study found that bronchial provocation tests were more commonly positive in patients with migraine than those without. So, inflammation was discussed as the common pathology for both migraine and asthma [21].

Although many studies have investigated the potential mechanism underlying the link between asthma and migraine, they have not provided definitive findings. Immune mediators, cytokines, and neuropeptides have been commonly held responsible for this association [22]. Transient receptor potential vanilloid subfamily member 1 [TRPV1], which has been shown to play a role in the pathophysiology of both asthma and migraine, has been pointed out and emphasized. The activation of TRPV1 in c-fiber sensory nerves in the airways causes the emergence of asthma features such as bronchoconstriction, hypersecretion, and cough. In addition, TRPV1 also causes the release of neuropeptides in the nerve endings of trigeminal nociceptors, which initiates neurogenic 
inflammation and results in a migraine attack through vasodilatory effects [23-25]. Mast cell activity has also been studied. The role of mast cells in asthma is well known. It has been shown that intracranial mast cell degranulation triggers migraine headache through prolonged stimulation of meningeal nociceptors. Furthermore, mast cells induce the release of corticotropin releasing hormone that is known to increase the frequency and intensity of migraine attacks $[25,26]$. Aupiais et al. reported that the risk of migraine is reduced in children receiving antiasthmatic treatment [27]. Similar to many prior studies, Turan et al. reported that the migraine frequency markedly increased in women and asthmatics [8]. Nartin et al., in a similar but larger series, found a marked increase in the new-onset migraine risk among women with asthma compared with men [11].

Our study has some limitations. One of them is its retrospective design. Additionally, as the study was retrospective, we were not able to establish a clear relationship between the two conditions, which has been couldn't understood by former studies.

In conclusion, our study is very important because it is one of the few studies that examined the relationship between asthma and migraine in childhood. Furthermore, it is important in that it is one of the largest pediatric studies performed so far in our country. The risk of migraine is significantly increased in school age children with asthma. This supports the hypothesis asserting that asthma and migraine share a common pathophysiological mechanism. Clinicians following the pediatric age group should be more frequently suspected of migraine in differential diagnosis. A greater number of studies with larger population size that are based on the known comorbidities and pathogenesis of asthma and migraine could help develop new treatments for both diseases.

Author contributions: All authors have sufficiently contributed to the study, and agreed with the results and conclusions.

Funding: No funding source is reported for this study.

Declaration of interest: No conflict of interest is declared by authors.

\section{REFERENCES}

1. Centers for Disease Control and Prevention, Summary Health Statistics for U.S. Adults: National Health Interview Survey; 2012. Available at: www.cdc.gov/nchs/fastats/ asthma.htm

2. Asher MI, Montefort S, Björkstén B, et al; ISAAC Phase Three Study Group. Worldwide time trends in the prevalence of symptoms of asthma, allergic rhinoconjunctivitis, and eczema in childhood: ISAAC Phases One and Three repeat multicountry cross-sectional surveys. Lancet. 2006 Aug 26;36(9537):733-43. https://doi.org/10.1016/S0140-6736 (06)69283-0

3. Eder W, Ege MJ, von Mutius E. The asthma epidemic. N Engl J Med. 2006;355:2226-35. https://doi.org/10.1056/ NEJMra054308 PMid:17124020

4. Stovner LJ, Hagen K, Jensen R, et al. The global burden of headache: a documentation of headache prevalence and disability worldwide. Cephalagia. 2007;27:193-210. https://doi.org/10.1111/j.1468-2982.2007.01288.x PMid:17381554
5. Abu-Arafeh I, Razak S, Sivaraman B, Graham C. Prevalence of headache and migraine in children and adolescents: a systematic review of population-based studies. Dev Med Child Neurol. 2010 Dec;52(12):1088-97. https://doi.org/ 10.1111/j.1469-8749.2010.03793.x PMid:20875042

6. Aupiais C, Wanin S, Romanello S, et al. Association Between Migraine and Atopic Diseases in Childhood: A Potential Protective Role of Anti-Allergic Drugs. Headache. 2017; 57(4):612-624. https://doi.org/10.1111/head.13032 PMid: 28160287

7. Tucker GF Jr. Pulmonary migraine. Ann Otol Rhinol Laryngol. 1977;86(5 Pt 1):671-676. https://doi.org/10.1177/ 000348947708600524 PMid:911148

8. Turan MO, Susuz ÇÇ, Turan PA. Presence of Headache and Migraine in Asthma Patients. Turk Thorac J. 2017 Apr;18(2):47-51. https://doi.org/10.5152/TurkThoracJ.2017 .16008 PMid:29404159 PMCid:PMC5783079

9. Graif $Y$, Yigla M, Tov N, Kramer MR. Value of negative aeroallergen skinprick test result in the diagnosis of asthma in young adults: correlative study with metacholine challenge testing. Chest. 2002;122:821-825. https://doi.org/ 10.1378/chest.122.3.821 PMid:12226019

10. Zhang X, Strassman AM, Burstein R, Levy D. Sensitization and activation of intracranial meningeal nociceptors by mast cell mediators. J Pharmacol Exp Ther. 2007;322:806812. https://doi.org/10.1124/jpet.107.123745 PMid: 17483291

11. Martin VT, Fanning KM, Serrano D, Buse DC, Reed ML, Lipton $\mathrm{RB}$. Asthma is a risk factor for new onset chronic migraine: results from the American migraine prevalence and prevention study. Headache. 2016;56:118-131. https://doi.org/10.1111/head.12731 PMid:26581563

12. Crapo RO, Casaburi R, Coates AL, et al. Guidelines for methacholine and exercise challenge testing-1999. This official statement of the American Thoracic Society was adopted by the ATS Board of Directors, July 1999. Am J Respir Crit Care Med. 2000 Jan;161(1):309-29. https://doi.org/10.1164/ajrccm.161.1.ats11-99 PMid:10619836

13. Global Initiative for Asthma. Global Strategy for Asthma Management and Prevention, 2020. Available at: https://ginasthma.org/2020

14. International Classification of Headache Disorders-3 [beta version]. Cephalalgia 2013;33:629-808. https://doi.org/ 10.1177/0333102413485658 PMid:23771276

15. McAbee GN, Morse AM, Assadi M. Pediatric Aspects of Headache Classification in the International Classification of Headache Disorders-3 (ICHD-3 beta version). Curr Pain Headache Rep. 2016 Jan;20(1):7. https://doi.org/ 10.1007/s11916-015-0537-5 PMid:26749046

16. Le H, Tfelt-Hansen P, Russell MB, et al. Co-morbidity of migraine with somatic disease in a large population-based study. Cephalalgia. 2011 Jan;31(1):43-64. https://doi.org/ 10.1177/0333102410373159 PMid:20974590

17. Aamodt AH, Stovner LJ, Langhammer A, Hagen K, Zwart JA. Is headache related to asthma, hay fever, and chronic bronchitis? The Head-HUNT Study. Headache. 2007 Feb;47(2):204-12. https://doi.org/10.1111/j.1526-4610. 2006.00597.x PMid:17300360

18. Davey G, Sedgwick P, Maier W, Visick G, Strachan DP, Anderson HR. Association between migraine and asthma: matched case-control study. Br J Gen Pract. 2002 Sep;52(482):723-7. PMID:12236275 
19. Lateef TM, Cui L, Nelson KB, Nakamura EF, Merikangas KR. Physical comorbidity of migraine and other headaches in US adolescents. J Pediatr. 2012 Aug;161(2):308-13. https://doi.org/10.1016/j.jpeds.2012.01.040 PMid:22381023 PMCid:PMC4408276

20. Peng YH, Chen KF, Kao CH, et al. Risk of Migraine in Patients With Asthma: A Nationwide Cohort Study. Medicine (Baltimore). 2016 Mar;95(9):e2911. https://doi.org/10.1097/ MD.0000000000002911 PMid:26945388 PMCid: PMC4782872

21. Kaleagasi H, Özgür E, Özge C, Özge A. Bronchial hyperreactivity in migraine without aura: is it a new clue for inflammation? Headache. 2011 Mar;51(3):426-431. https://doi.org/10.1111/j.1526-4610.2010.01798.x PMid:21352216

22. Kemper RH, Meijler WJ, Korf J, Ter Horst GJ. Migraine and function of the immune system: a meta-analysis of clinical literature published between 1966 and 1999. Cephalalgia. 2001 Jun;21(5):549-57. https://doi.org/10.1046/j.14682982.2001.00196.x PMid:11472381
23. Meents JE, Neeb L, Reuter U. TRPV1 in migraine pathophysiology. Trends Mol Med. 2010 Apr;16(4):153-9. https://doi.org/10.1016/j.molmed.2010.02.004 PMid:20347391

24. Waeber C, Moskowitz MA. Migraine as an inflammatory disorder. Neurology. 2005 May 24;64(10 Suppl 2):S9-15. https://doi.org/10.1212/wnl.64.10_suppl_2.s9 PMid:15911785

25. Levy D. Migraine pain, meningeal inflammation, and mast cells. Curr Pain Headache Rep. 2009 Jun;13(3):237-40. https://doi.org/10.1007/s11916-009-0040-y PMid:19457286

26. Theoharides TC, Donelan J, Kandere-Grzybowska K, Konstantinidou A. The role of mast cells in migraine pathophysiology. Brain Res Brain Res Rev. 2005 Jul;49(1):65-76. https://doi.org/10.1016/j.brainresrev.2004. 11.006 PMid:15960987

27. Aupiais C, Wanin S, Romanello S, et al. Association Between Migraine and Atopic Diseases in Childhood: A Potential Protective Role of Anti-Allergic Drugs. Headache. 2017 Apr;57(4):612-24. https://doi.org/10.1111/head.13032 PMid:28160287 